дослідження: зб. наук. пр. - Луганськ, 2006. - Вип. 6. - С. 90-97. 4. Сорокина А. В. Социологический анализ культуры потребления / А. В. Сорокина // Вісник Харківського університету імені В. Н. Каразіна. - 2005. - № 652. Соціологічні дослідження сучасного суспільства: методологія, теорія, методи. - С. 92-95.

Тетяна Герасимчук

\title{
НОВІ МОЖЛИВОСТІ ІНФОРМАЦЙНИХ ТЕХНОЛОГІЙ У СИСТЕМІ ВИЩОЇ ПРОФЕСІЙНОЇ ОСВІТИ
}

Герасимчук Т. В. Нові можливості інформаційних технологій у системі вищої професійної освіти.

У статті здійснено теоретичний аналіз навчальних можливостей інформаційних технологій у системі вищої професійної освіти, що дозволяють формувати професійну компетентність студентів автомобільно-дорожнього профілю; обгрунтовано умови формування й визначено структурні компоненти та функції професійної компетентності студентів автомобільно-дорожнього університету на основі електронних засобів навчання.

Ключові слова: інформаційні технології, інформаційна компетентність, функції професійної компетентності фахівця, компоненти професійної компетентності, умови формування професійної компетентності студентів автомобільно-дорожнього профілю.

Герасимчук Т. В. Новые возможности информационных технологий в системе высшего профессионального образования.

В статье осуществлен теоретический анализ учебных возможностей информационных технологий в системе высшего образования, позволяющие формировать профессиональную компетентность студентов автомобильно-дорожного профиля; обоснованы условия формирования и определены структурные компоненты и функции профессиональной компетентности студентов автомобильно-дорожного университета на основе электронных средств обучения.

Ключевые слова: информационные технологии, информационная компетентность, функции профессиональной компетентности специалиста, компоненты профессиональной компетентности, условия формирования профессиональной компетентности студентов автомобильно-дорожного профиля.

Gerasymchuk T. V. The new opportunities of information technology in the system of higher professional education.

This article provides theoretical analysis of learning opportunities of information technology in the system of higher education, allowing students of auto-road profile to form professional competence; the conditions of forming are proven and the structural components and functions of the professional competence of students of the Automobile and Highway University are identified and based on the e-learning .

Key words: information technology, informative competence, functions of the professional competence specialist, components of the professional competence, conditions of the professional competence of students of the Automobile and Highway University that are based on e-learning. 
На сучасному етапі суспільного розвитку України відбуваються глобальні соціальні й економічні зміни, що зумовлюють процеси модернізації системи вищої освіти. У період кардинальних соціокультурних зрушень, які характеризуються інтеграцією української економіки до світової, іiі оновленням на основі нанотехнологій, відкритістю освіти, процесами глобалізації, зростанням значення інтеркультурних комунікацій, суспільству потрібні фахівці, здатні акумулювати нові якості теорії і практики, сучасну культуру, принципи креативного мислення й самоосвітньої діяльності, самовдосконалення протягом усього життя.

У цих умовах традиційна парадигма вищої професійної освіти актуалізує ресурси інформаційних технологій у процесі підготовки мобільних, компетентних і затребуваних професіоналів, від яких залежатимуть темпи й ефективність багатьох перетворень, зростання культури й духовного багатства. Майбутньому фахівцеві необхідно вміти здійснювати пошук і перероблення інформації, застосовувати іiі на практиці, бути налаштованим на самовдосконалення, самоосвіту. Тому основоположними є готовність студента до самоосвітньої діяльності, наявність умінь учитися, внутрішня мотивація навчання. Тож у зв'язку з цим гостро постає потреба розв'язання проблеми розвитку професійної компетентності і професійно значущих якостей особистості у студентів- майбутніх фахівців автомобільно-дорожньої галузі - на основі електронних засобів навчання.

Із уведенням нових стандартів підготовка кваліфікованих фахівців, конкурентоспроможних на ринку праці, здатних до компетентної, відповідальної й ефективної діяльності за своєю професією, неможлива без упровадження інноваційних технологій, використання яких у практиці навчання $є$ обов'язковою умовою підвищення якості навчання [7].

Дослідженню нових можливостей інформаційних технологій у системі вищої професійної освіти присвячені роботи С. Бешенкова, Л. Гур'є, Л. Долінера, А. Єршова, Е. Когана, І. Роберт та інших.

Інформаційну компетентність як ключову, що забезпечує практично всі аспекти діяльності людини, й необхідну для самореалізації особистості виокремлюють Б. Оскарсон, Е. Клімов, D. Münk, W. Hutmacher та ін. У низці робіт інформаційна компетентність визначається як мета підготовки фахівця і невід'ємний складник його професійної компетентності (А. Бєлкін, І. Дзегеленок, Е. Зеєр, А. Кузнецов, Є. Машбиц, С. Хеннер та ін.).

Проблеми формування професійної компетентності студентів розкрито у працях В. Байденко, Ю. Балашова, Л. Барановської, Г. Бондаренко, Т. Васильєвої, Г. Васяновича, О. Горошкіної, Р. Гуревича, Г. Гуторова, І. Дроздової, Г. Ібрагімова, Г. Кашканової, Л. Паламар, В. Пікельної, Т. Рукас, В. Сапронової та ін. Більшість цих досліджень присвячено проблемам формування у студентів сукупності компетенцій під час викладання як мовних, так і загальнонаукових або технічних дисциплін.

Загальнометодичні питання застосування технічних засобів і комп'ютерів у процесі навчання задля його інтенсифікації відображено в роботах C. Архангельського, В. Беспалька, Т. Везірова, Б. Гершунського, С. Машбиця, В. Монахова, Є. Полат, І. Роберт та ін. Водночас недостатньо розроблені науковометодичні підходи до формування професійної компетентності фахівців автомобільно-дорожнього профілю 3 урахуванням напрямку підготовки на основі електронних засобів навчання.

Mema cmammi - показати значення інформаційних технологій у системі вищої професійної освіти для формування професійної компетентності студентів 
автомобільно-дорожнього профілю.

Інформаційна компетентність майбутнього інженера розуміється не тільки як інформаційні знання, уміння і навички, що будуть необхідні для розв'язання професійних завдань, але й як знання багатьох інформаційних систем у виробництві, уміння підтримувати і розвивати свій рівень кваліфікації в умовах постійного оновлення комунікаційних засобів, а також як готовність оперативно засвоювати нові інформаційні системи і технології [1;3].

Розв'язання цих завдань пов'язане $з$ необхідністю усунення суперечностей між:

- необхідністю системної підготовки майбутніх фахівців у галузі інформаційних технологій і нерозробленістю технології, іiі реалізації у вищій технічній школі;

- сформованою системою підготовки студентів технічних спеціальностей у галузі інформаційних технологій, що не враховує компетентнісну парадигму освіти, 3 одного боку, i вимогами державних освітніх і міжнародних стандартів у період переходу до компетентнісної моделі освіти, з іншого боку;

- актуальністю посилення інформаційного складника у структурі професійної компетентності майбутнього інженера 3 урахуванням профілю його підготовки i нечисленністю досліджень цієї проблеми [3].

Формування професійної компетентності студентів автомобільно-дорожнього університету на основі електронних засобів навчання буде здійснюватися більш ефективно, якщо:

- науково осмислено потенціал компетентнісного підходу у професійній підготовці майбутніх фахівців;

- розроблена ефективна модель процесу формування професійної компетентності студентів автомобільно-дорожнього університету на основі електронних засобів навчання, представлені в узагальненому вигляді компоненти цілісного освітнього процесу, зумовлені специфічними особливостями підготовки фахівців автомобільно-дорожніх спеціальностей;

- використано програмно-методичне забезпечення, адаптоване до ступеня, рівня освіти та особливостей професійної діяльності випускників.

Підгрунтям для розроблення моделі формування професійної компетентності майбутніх економістів повинні також бути загальнодидактичні принципи навчання (науковості, наочності, систематичності та послідовності, доступності, залучення студентів до навчального процесу, творчої активності студентів, гуманізму, індивідуального підходу в навчанні) та специффічні принциии професійного навчання (поєднання навчання з виробничою діяльністю, спрямованість на результат, принцип моделювання професійної діяльності в навчальному процесі, професійної мобільності та модульності, інформатизації освіти й комп'ютеризації навчального процесу, відтворення процесу і результатів навчання в моделі підготовки фахівця) [7, с. 118]. Оскільки основними положеннями, на яких вибудовується процес формування професійної компетентності студентів автомобільно-дорожнього університету, $\epsilon$ принципи, ми вважали за доцільне додати також до системи принципів такі, як системність, інтерактивність, професійна спрямованість.

Ці принципи мають як загальнопедагогічний, так і специфічний характер, що відображає спрямованість нашого дослідження на розроблення моделі формування професійної компетентності студентів автомобільно-дорожнього університету на основі електронних засобів навчання.

Аналіз наукової й навчально-методичної літератури дозволив нам визначити функції, які, на наш погляд, найбільш повно відображають зміст професійної 
компетентності фахівця автомобільно-дорожнього профілю:

- практико-операційна (діяльнісна), що полягає в удосконаленні отриманих знань у галузі електронних засобів навчання у вигляді умінь і навичок під час роботи 3 ними;

- мотиваційно-спонукальна - розвиток і набуття зрілої форми думок, мотивів, цінностей, усієї спрямованості особистості, самоствердження у власній професійній діяльності, реалізація творчого потенціалу, набуття авторитету в очах колег і самого себе;

- гностична - активізація пізнавальної, інтелектуальної діяльності особистості, засвоєння накопичених у галузі електронних засобів навчання знань, розширення кругозору, ерудиції, спрямованих на перспективний розвиток;

- комунікативна, що виявляється в умінні організовувати роботу команди співробітників під час розроблення проектів, ведення діалогу 3 урахуванням національно-регіональних і соціально-демографічних чинників;

- контрольно-оцінна (рефлексивна) - усвідомлення фахівцем автомобільнодорожнього профілю повноти своїх знань, поведінки, морального обличчя й інтересів, цілісна оцінка самого себе як професіонала своєї справи [2; 4].

На наш погляд, у цій сукупності функцій професійної компетентності системоутворювальною $є$ практико-операційна (діяльнісна), оскільки компетентність, як було зазначено раніше, виявляється в умінні розв'язувати проблемні завдання в предметній галузі, технологічно проектувати власну професійну діяльність, що вирізняється якістю і результативністю. Система функцій дозволила представити професійну компетентність спеціаліста автомобільно-дорожнього профілю як єдність компонентів: мотиваційно-ціннісного, когнітивного, діяльнісного, рефлексивного. Кожен із указаних компонентів реалізується в певних компетенціях фахівця [5; 6].

Отже, можна зробити висновок щодо ефективності застосування інформаційних технологій навчання у процесі формування професійної компетентності студентів автомобільно-дорожніх спеціальностей. Перспективами подальших досліджень $\epsilon$ дидактичне обгрунтування ефективності дистанційної інтернет-освіти. Загалом результати дослідження можуть бути оптимально використані в навчальному процесі ВНЗ України, що здійснюють підготовку майбутніх інженерів автомобільної галузі.

\section{Література}

1. Гурье Л. И. Проектирование педагогических систем: [учеб. пособие]/ Л. И. Гурье. - Казань : Казан. гос. технол. ун-т, 2004. - 212 с. 2. Роберт И. В. Теория и методика информатизации образования (психолого-педагогический и технологический аспекты): [Текст] / И. В. Роберт; Рос. акад. образования, Ин-т информатизации образования. - М. : ИИО РАО, 2007. - 234 с. 3. Ершов А. П. Основы информатики и вычислительной техники : [проб. учеб. пособие для сред. заведений: в 2-х ч. Ч.1.] / под ред. А. П. Ершова, В. М. Монахова. - М. : Просвещение, 1985. - 96 с. 4. Климов Е. А. Психология профессионального самоопределения : [учеб. пособие для студ. высш. пед. учеб. заведений] / Евгений Александрович Климов. - М. : Изд. центр «Академия», 2005. - 304 c. 5. Simonová N. «W. Hutmacher, D. Cochrane, N. Bottani (eds.) : In Pursuit of Equity in Education: Using International Indicators to Compare Equity Policies. Sociologický časopis / Czech Sociological Review / N. Simonová, D. Greger. - 39 (3) : 425-429 s. 6. Theorie und Praxis der Kompetenzfeststellung im Betrieb. - Status quo und Entwicklungsbedarf by Eckart Severing and Hans D. Münk (Aug 2009). $-240 \mathrm{~s}$. 